\title{
Efektivitas Model Pembelajaran Reciprocal Teaching terhadap Peningkatan Kemampuan Pemahaman Konsep Matematis Siswa pada Materi Logaritma
}

\author{
Saniah $^{1}$, Resy Nirawati $^{2}$, Mariyam $^{3}$ \\ STKIP Singkawang, Singkawang, Indonesia \\ riasaniah95@gmail.com ${ }^{1, *)}$, resynirawati@gmail.com ${ }^{2}$, mariyam.180488@ gmail.com $^{3}$ \\ ${ }^{*}$ Corresponding author
}

Kata kunci :

Reciprocal Teaching; Pemahaman

Konsep Matematis; Logaritma

\begin{abstract}
ABSTRAK
Penelitian ini bertujuan untuk mengetahui perbedaaan peningkatan kemampuan pemahaman konsep matematis siswa setelah diberikan model pembelajaran Reciprocal Teaching pada materi Logaritma di kelas X MA Yasti Singkawang, besarnya aktivitas siswa, besarnya kemandirian siswa, serta untuk mengetahui ketuntasan belajar siswa secara individual maupun klasikal. Jenis penelitian yang digunakan adalah kuantitatif, bentuk penelitian Nonequivalent Control Group. Populasi penelitian adalah siswa kelas $X$ yang terdiri dari 3 kelas yang berjumlah 75 orang. Sampel penelitian diambil menggunakan purposive sampling. Adapun yang menjadi kelas eksperimen adalah kelas XB yang berjumlah 25 orang dan kelas kontrol adalah kelas XA yang berjumlah 25 orang. Hasil penelitian menunjukkan bahwa: (1) terdapat peningkatan kemampuan pemahaman konsep matematis siswa kelas eksperimen sebesar 0,39 yang berada pada kriteria sedang dan peningkatannya lebih tinggi dibandingkan peningkatan kemampuan pemahaman konsep matematis siswa pada kelas kontrol, selanjutnya berdasarkan perhitungan uji-t dua sampel diketahui bahwa terdapat perbedaaan peningkatan kemampuan pemahaman konsep matematis siswa yang signifikan setelah diberikan model pembelajaran Reciprocal Teaching pada materi logaritma, (2) Aktivitas belajar siswa selama mengikuti pembelajaran dengan menggunakan model pembelajaran Reciprocal Teaching sangat aktif dengan persentase sebesar 78,69\%, (3) Ketuntasan belajar siswa mencapai KKM 68 yaitu sebesar 77,78 dan ketuntasan klasikal melampaui 75\%, (4) Hasil angket kemandirian belajar siswa diperoleh rata-rata seluruh angket 80,16 dengan kategori baik.
\end{abstract}

\section{PENDAHULUAN}

Matematika adalah ilmu yang berfungsi mengembangkan kemampuan berhitung, mengukur, menurunkan, dan menggunakan rumus matematika yang diperlukan dalam kehidupan sehari-hari melalui pengukuran dan geometri, aljabar, peluang dan statistic. Oleh sebab itu matematika adalah 
satu di antara mata pelajaran yang penting dalam dunia pendidikan, sehingga matematika dijadikan sebagai mata pelajaran yang pokok dalam setiap jenjang pendidikan. Dalam belajar matematika, pemahaman konsep merupakan bagian penting yang harus dicapai oleh siswa. Kesalahan mempelajari suatu konsep terdahulu akan berpengaruh terhadap penguasaan konsep selanjutnya, karena matematika merupakan pelajaran terstruktur. Hal ini sependapat dengan pernyataan Jihad dan Haris (2012: 149) menyatakan bahwa suatu konsep disusun berdasarkan konsep-konsep sebelumnya dan akan menjadi dasar bagi konsep-konsep selanjutnya, sehingga pemahaman yang sala terhadap suatu konsep, akan berakibat pada kesalahan pemahaman terhadap konsep-konsep selanjutnya. Penguasaan konsep materi dalam matematika haruslah menjadi prioritas utama. Apabila siswa dapat menguasai suatu konsep dengan baik, maka berbagai macam variasi soal dan permasalahannya akan mudah diatasi.

Pemahaman konsep matematis merupakan satu di antara tujuan dari pembelajaran matematika disekolah. Selain itu, NCTM (2000) menyatakan bahwa visi dari matematika sekolah adalah berdasarkan pada pembelajaran matematika siswa yang disertai dengan pemahaman. Bransford, Brown dan Cocking (NCTM, 2000: 20) memaparkan belajar matematika dengan disertai pemahaman konsep juga merupakan komponen terpenting dari kemampuan, bersama dengan kecakapan pengetahuan faktual dan prosedural. Belajar matematika dengan disertai pemahaman sangat diperlukan untuk memungkinkan siswa menyelesaikan masalah yang akan mereka hadapi pada soal lain. Kemampuan pemahaman konsep matematis siswa dinyatakan rendah hal ini diperkuat oleh penelitian yang dilakukan Elcho (2014) yang menunjukkan bahwa suatu permasalahan dalam pembelajaran matematika di SMP IT Nurul Iman Pesawaran adalah rendahnya kemampuan pemahaman konsep matematis siswa sehingga mempengaruhi tercapainya tujuan pembelajaran di SMP tersebut. Hasil penelitian Elcho menunjukkan kemampuan siswa menyatakan ulang sebuah konsep sebesar $40 \%$, kemampuan siswa membedakan contoh dan non contoh sebesar $18 \%$, dan mengklarisifikasikan konsep atau algoritma ke pemecahan masalah sebesar 25\%. Namun untuk memahami konsep matematika memang bukanlah hal mudah.

Pentingnya pemahaman konsep matematika siswa juga dikemukakan oleh Juliyanti, Rosmaiyadi dan Mariyam (2018:2) bahwa membangun pemahaman konsep dalam pembelajaran matematika harus dikembangkan dan dimiliki siswa dalam proses pembelajaran siswa perlu dibiasakan untuk siswa lebih memahami konsep dalam memecahkan masalah, baik masalah matematis maupun masalah dalam kehidupan sehari-hari agar siswa memperoleh pengetahan serta keterampilan yang dimiliki untuk menyelesaikan soal. Definisi pemahaman konsep yang dikemukakan oleh Buyung, Nirawati dan Kusumawati (2016:4) bahwa pemahaman konsep dalam matematika sebagai kemampuan mengaitkan notasi dan simbol matematika yang relevan dan mengkombinasikan ke dalam rangkaian penalaran yang logis. Hal ini didukung (Ruseffendi, 2006:156) yang mengatakan bahwa terdapat banyak anakanak yang setelah belajar matematika pada bagian sederhana pun banyak tidak dipahami, banyak konsep yang dipahami secara keliru. Pada akhirnya matematika dianggap sebagai mata pelajaran yang sulit, ruwet, dan siswa enggan untuk mempelajarinya. Anggapan seperti itu mengakibatkan rendahnya pemahaman konsep siswa sehingga dapat berdampak pada hasil belajar siswa.

Selanjutnya penulis melakukan wawancara dengan guru matematika untuk mengetahui hasil belajar siswa pada pelajaran matematika. Berdasarkan wawancara dengan guru matematika MA Yasti Singkawang diperoleh informasi bahwa hasil belajar siswa pada pelajaran matematika masih rendah. Hal tersebut terlihat dari daftar nilai tahun pelajaran sebelumnya yang menunjukkan bahwa hasil belajar pada logaritma rata-rata masih tergolong rendah dari 23 siswa yang di atas KKM yaitu sekitar $22 \%$ atau 5 siswa sedangkan yang tidak tuntas yaitu sekitar $78 \%$ atau 18 siswa. KKM untuk pelajaran matematika di MA Yasti Singkawang yaitu 68. Rendahnya nilai siswa sehingga tidak mencapai KKM mengindikasi bahwa kemampuan siswa dalam menyelesaikan soal matematika masih rendah yang salah satu faktornya adalah pada kemampuan siswa dalam memahami konsep. Hal tersebut diperkuat dengan hasil prariset yang dilakukan penulis di MA Yasti Singkawang. Penulis memberikan soal yang mengandung indikator pemahaman konsep pada materi bilangan berpangkat kepada 23 siswa dikelas $\mathrm{X}$. Adapun indikator pemahaman konsep dalam prariset ini, yaitu (1) mendefenisikan konsep secara 
tulisan, (2) mengklarisifikasikan objek-objek menurut sifat-sifat tertentu, (3) mengaplikasikan konsep atau algoritma pada pemecahan masalah.

Berdasarkan hasil prariset dapat diketahui pemahaman konsep matematis siswa masih tergolong rendah. Selain itu, skor yang dicapai siswa pada setiap indikator pemahaman konsep matematis siswa masih tergolong rendah. Pada soal nomor 1 diharapkan siswa mampu mendefenisikan ulang konsep bilangan berpangkat kedalam bentuk akar yang telah disajikan yaitu $\sqrt[5]{32}=2, \sqrt{4}=2$ tapi masih banyak siswa yang belum bias mengerjakan dengan benar. Pada soal nomor 2 diharapkan siswa dapat mengklarisifikasikan objek menurut sifat-sifat tertentu dari soal yang diberikan adalah $-x^{2}+6 x-$ $9=0$, tetapi siswa masih banyak yang belum memahami dan menyelesaikan dengan benar. Pada soal nomor 3 diharapkan siswa mampu membedakan contoh dan non contoh dari sifat perpangkatan, tetapi masih banyak siswa yang belum bias menjawab dengan benar dan memberikan alasan yang tepat.

Dari hasil keseluruhan prariset dapat dilihat bahwa masih rendahnya kemampuan pemahaman konsep matematis siswa, maka selanjutnya penulis melakukan observasi di kelas untuk mengetahui mamsalah apa saja yang terjadi pada saat pembelajaran. Dari hasil observasi ditemukan bahwa proses pembelajaran matematika saat ini cenderung menerapkan pembelajaran langsung yang berpusat pada guru, dimana guru menjelaskan suatu konsep kemudian siswa hanya duduk mendengarkan, dan siswa tidak berani untuk menanyakan materi yang belum dipahami serta tidak berani untuk mengeluarkan pendapat-pendapat mereka. Model pembelajaran langsung adalah model pembelajaran yang dirancang secara khusus untuk menunjang proses belajar siswa berkenaan dengan pengetahuan prosedural dan pengetahuan deklaratif yang terstruktur dengan baik dan dapat dipelajari selangkah demi selangkah Jihad dan Haris (2012 : 27). Guru juga kurnag melibatkan peran aktif siswa sehingga aktivitas belajar siswa masih tergolong rendah, dan mengakibatkan kejenuhan dalam pembelajaran. Sardiman (2014:100) menyatakan sekolah merupakan tempat mengembangkan aktivitas. Oleh karena itu aktivitas sangat penting dalam pembelajaran.

Penyebab rendahnya aktivitas belajar siswa kurang aktif adalah kurang kesadaran dan keinginan dari diri siswa untuk belajar, kurangnya dorongan untuk menumbuhkan kemandirian belajar siswa. Kemandirian merupakan satu diantara unsure terpenting yang harus dimiliki siswa dalam proses belajar mengajar, dan dapat memicu dalam memperbaiki prestasi dari proses belajar tersebut, karena menyangkut inisiatif siswa Ali (Danianti, 2013: 109). Jadi kemandirian disini menekankan pada aktivitas siswa dalam belajar yang penuh tanggung jawab demi keberhasilan dalam belajarnya. Kemandirian belajar akan mampu mengembangkan kemampuan kognitif yang tinggi, hal ini disebabkan karena siswa terbiasa menghadapi tugas dan mencari pemecahannya sendiri dengan menggali sumber belajar yang ada serta mengadakan diskusi dengan teman bila mengalami kesulitan.

Dilihat dari permasalahan di atas bahwa model pembelajaran yang digunakan guru belum sepenuhnya berhasil, sehingga diperlukan adanya perubahan model pembelajaran. Model pembelajaran yang digunakan dalam pembelajaran matematika seharusnya dapat menumbuhkan motivasi siswa untuk belajar. Selain itu, model pembelajaran yang digunakan harus menyenangkan dan bermakna agar siswa yang mengikuti proses belajar mengajar tidak bosan dan dapat mengikuti pelajaran dengan baik. Sehingga dengan adanya perubahan model pembelajaran yang tepat dapat meningkatkan pemahaman konsep matematis siswa dan dapat mempengaruhi aktivitas siswa serta dapat mempengaruhi kemandirian siswa dalam belajar. Salah satu model pembelajaran yang melibatkan peran aktif siswa adalah model pembelajaran Reciprocal Teaching. Model Reciprocal Teaching sangat cocok diterapkan dalam masalah penelitian ini yaitu pemahaman konsep matematis siswa pada pembelajaran matematika karena melalui model ini siswa diharapkan belajar melalui mengalami bukan menghapal.

Reciprocal Teaching merupakan suatu model pembelajaran yang dilaksanakan agar tujuan pembelajaran tercapai dengan tepat melalui proses belajar mandiri dan siswa mampu menyajikannya didepan kelas. Menurut Elcho (2014), model Reciprocal Teaching mengandung empat strategi, yaitu membuat pertanyaan (question generating), mengklarisifikasikan istilah-istilah yang sulit dipahami 
(clarifying), memprediksi materi lanjut (predicting), dan merangkum (summarizing). Menurut Huda (2014: 129), melalui model Reciprocal Teaching (pembelajaran terbalik) ini siswa dapat mengembangkan kemauan belajar mandiri, siswa memiliki kemampuan mengembangkan pengetahuannya sendiri dan guru berperan sebagai fasilitator, mediator, dan manager dlam proses pembelajaran. Hasil penelitian Atiqah (2014) menunjukkan bahwa kemampuan pemahaman konsep matematis siswa mendapat pelakuan lebih baik daripada pembelajaran langsung. Sehingga dapat disimpulkan bahwa model pembelajaran Reciprocal Teaching efekif terhadap kemampuan pemahaman konsep disbanding dengan pembelajaran langsung.

Siswa juga diharapkan dapat meningkatkan pemahaman konsep matematika mereka. Hal ini dikarenakan ketika siswa mampu mengembangkan langkah-langkah dalam Reciprocal Teaching berarti mereka dapat menemukan dan menyelidiki materi yang dibahas secara mandiri sehingga hasil yang diperoleh akan tahan lama dalam ingatan dan tidak mudah dilupakan oleh siswa. Dalam hal ini, mandiri tidak diartikan siswa harus mengkontruksi konsep secara individual, tetapi mereka dapat mendiskusikan materi tersebut dengan siswa yang lain. Dengan menemukan materi secara mandiri, pengertian siswa tentang suatu konsep merupakan pengertian yang benar-benar dipahami oleh siswa. Alasan penulis memilih model pembelajaran Reciprocal Teaching adalah karena dengan model Reciprocal Teaching siswa belajar dengan pengertian sehingga siswa tidak mudah lupa, siswa belajar mandiri dan termotivasi untuk belajar. Model pembelajaran Reciprocal Teaching dapat meningkatkan antusias siswa dalam pembelajaran karena siswa dituntut untuk aktif berdiskusi dan menjelaskan pekerjaannya dengan baik sehingga penguasaan konsep pada materi logaritma dapat dicapai dan nilai siswa menjadi meningkat.

\section{METODE PENELITIAN}

Darmadi (2014: 40) mengatakan bahwa metode penelitian adalah suatu cara ilmiah untuk mendapatkan data dengan tujuan tertentu. Berdasarkan definisi tersebut, metode yang digunakan dalam penelitian ini adalah metode eksperimen. Jenis penelitian yang digunakan dalam penelitian ini adalah jenis penelitian kuantitatif, karena data yang diperoleh berhubungan dengan angka-angka yang dapat dihitung secara matematis dan sistematis. Desain dalam penelitian ini adalah eksperimen semu (Quasy-Exsperimental) dengan bentuk Nonequivalent control group. Penulis memilih quasy experimental karena dalam penelitian ini mempunyai kelompok kontrol, tetapi tidak dapat berfungsi sepenuhnya untuk mengontrol variable-variabel luar yang mempengaruhi pelaksanaan eksperimen. Serta adanya rancangan non-equivalent control group dikarenakan fokus dalam penelitian adalah untuk mengetahui kemampuan pemahaman konsep matematis siswa berdasarkan hasil pretest dan posttest pada kelas eksperimen setelah dikenakan model Reciprocal Teaching dan kelas kontrol setelah dikenakan model pembelajaran langsung. Adapun desain penelitian ini dapat dilihat pada Tabel 1.

Tabel 1 Desain Penelitian Nonequivalent Control Group

\begin{tabular}{cccc}
\hline Kelompok & Pretest & Perlakuan & Posttest \\
\hline Eksperimen & $\mathrm{O}_{1}$ & $\mathrm{X}_{1}$ & $\mathrm{O}_{2}$ \\
Kontrol & $\mathrm{O}_{3}$ & $\mathrm{X}_{2}$ & $\mathrm{O}_{4}$ \\
\hline & & & (Darmadi, 2014:238)
\end{tabular}

Keterangan :

$\mathrm{O} 1=$ Tes awal (pretest) pada kelas eksperimen

$\mathrm{O} 2=$ Tes akhir (post-test) pada kelas eksperimen

$\mathrm{X}_{1}=$ Perlakuan pada kelas eksperimen dengan pembelajaran menggunakan model pembelajaran Reciprocal Teaching.

$\mathrm{O} 3=$ Tes awal $($ pretest $)$ pada kelas kontrol

$\mathrm{O} 4=$ Tes awal (post-test) pada kelas kontrol

$\mathrm{X}_{2}=$ Perlakuan pada kelas kontrol yaitu pembelajaran menggunakan model pembelajaran langsung. 
Populasi dalam penelitian ini adalah seluruh siswa kelas X MA Yasti Singkawang yang terdiri dari tiga kelas yaitu kelas $\mathrm{Xa}, \mathrm{Xb}$, dan $\mathrm{Xc}$ yang berjumlah 75 siswa. sampel penelitian ini terdiri dari dua kelas yaitu kelas $\mathrm{Xb}$ sebagai kelas eksperimen dan kelas Xa sebagai kelas kontrol. Adapun teknik pengambilan sampel yang digunakan dalam penelitian ini adalah teknik purposive sampling.

Untuk menganalisis data antara kelas eksperimen dan kelas kontrol digunakan langkah sebagai berikut. (1) Untuk menjawab sub masalah pertama yaitu mencari ketuntasan individual menggunakan rumus t-test 1 sampel dan mencari ketuntasan klasikal menggunakan rumus uji proporsi (2) Untuk menjawab sub masalah kedua yaitu mengetahui perbedaan peningkatan kemampuan pemahaman konsep matematis siswa antara siswa yang mendapatkan pembelajaran dengan menggunakan model Reciprocal Teaching dan siswa yang mendapatkan pembelajaran langsung pada materi logaritma dikelas X MA Yasti Singkawang, digunakan rumus $\mathrm{N}$-gain, dilanjutkan dengan pengujian normalitas skor indeks gain dengan menggunakan rumus chi-kuadrat, pengujian homogenitas menggunakan rumus varians, dan uji perbedaan indeks skor gain menggunakan uji T-Test Korelasi. (3) Untuk menjawab sub masalah tiga akan dianalisis dengan menggunakan rumus persentase frekuensi aktivitas belajar siswa, dan (4) untuk menjawab sub masalah ke empat akan dianalisis dengan menggunakan rumus persentase setiap tanggapan.

\section{HASIL DAN PEMBAHASAN}

\section{Ketuntasan Belajar Siswa}

Berdasarkan hasil perhitungan normalitas post-test diketahui bahwa nilai $x^{2}{ }_{\text {hitung }}<x^{2}$ tabel yaitu $37,29<11,07$ yang menurut kriteria berarti Ho diterima dan Ha ditolak yang artinya data berdistribusi normal. Setelah berdistribusi normal maka dilakukan pengujian untuk menentukan ketuntasan belajar individual dan ketuntasan belajar klasikal. Berdasarkan hasil perhitungan diketahui bahwa rata-rata nilai ketuntasan individual siswa mencapai KKM yaitu > 68, sedangkan hasil perhitungan ketuntasan klasikal siswa diketahui bahwa siswa yang mendapatkan nilai KKM $>68$ mencapai $75 \%$.

Hasil penelitian ini seiring dengan penelitian yang dilakukan oleh Vahlia (2015) dari hasil kesimpulan penelitiannya menyatakan bahwa model pembelajaran Reciprocal Teaching dapat meningkatkan ketuntasan belajar siswa. Hal ini dapat dilihat dalam pelaksanaan siklus I dan II. Pada siklus I siswa yang mendapat nilai sesuai dengan KKM $\geq 75$ sebanyak 60,87\% sedangkan pada siklus II meningkat menjadi $82,61 \%$. Dengan demikian ketuntasan belajar pada siklus II telah mencapai ketuntasan belajar yaitu siswa yang mendapat nilai $\geq 75$ minimal sebanyak $80 \%$ dari jumlah seluruh siswa.

\section{Kemampuan Pemahaman Konsep Matematis Siswa}

Kemampuan pemahaman konsep matematis siswa dilihat dari hasil perhitungan rata-rata dari setiap indikator kemampuan pemahaman konsep. Dimana, indikator yang digunakan terdiri dari 3 indikator yaitu mendefenisikan konsep secara tulisan, mengklarisifikasikan objek menurut sifat-sifat tertentu, dan mengaplikasikan konsep atau algoritma pada pemecahan masalah. Berdasarkan perhitungan $\mathrm{N}$ Gain setiap indikator kemampuan pemahaman konsep pada kelas eksperimen dan kelas kontrol akan disajikan pada Tabel 2.

Berdasarkan Tabel 2 dapat diketahui bahwa nilai $\mathrm{N}$-gain pada setiap indikator kemampuan pemahaman konsep matematis siswa pada kelas eksperimen dan kelas kontrol mengalami peningkatan. Namun nilai $\mathrm{N}$-gain pada kelas eksperimen untuk setiap indikator kemampuan pemahaman konsep matematis siswa lebih tinggi dibanding nilai $N$-gain pada kelas kontrol. Berdasarkan paparan di atas dapat dilihat bahwa rata-rata nilai pretest dan post-test dikelas eksperimen lebih tinggi dibandingkan rata-rata nilai pretest dan post-test di kelas kontrol. Selain itu baik kelas eksperimen maupun kelas kontrol sama-sama mengalami peningkatan dari nilai pretest ke nilai posttest. Dapat dikatakan bahwa peningkatan kemampuan pemahaman konsep matematis siswa pada kelas yang menggunakan model Reciprocal Teaching lebih tinggi dari kelas yang menggunakan pembelajaran langsung. 
Tabel 2. Nilai $N$-gain Tiap Indikator

\begin{tabular}{|c|c|c|c|c|c|c|c|c|}
\hline \multirow{2}{*}{$\begin{array}{c}\text { Indikator } \\
\text { Kemampuan } \\
\text { pemahaman } \\
\text { konsep }\end{array}$} & \multicolumn{2}{|c|}{$\begin{array}{c}\text { Kelas } \\
\text { Eksperimen } \\
\end{array}$} & \multirow{2}{*}{$\begin{array}{l}N- \\
\text { gain }\end{array}$} & \multirow{2}{*}{ Kriteria } & \multicolumn{2}{|c|}{ Kelas Kontrol } & \multirow{2}{*}{$\begin{array}{l}N- \\
\text { gain }\end{array}$} & \multirow{2}{*}{ Kriteria } \\
\hline & Pretest & Posttest & & & Pretest & Posttest & & \\
\hline $\begin{array}{l}\text { Mendefenisikan } \\
\text { konsep secara } \\
\text { tulisan (4) }\end{array}$ & 2,5 & 3,02 & 0,35 & Sedang & 2,12 & 2,64 & 0,28 & Rendah \\
\hline $\begin{array}{l}\text { Mengklarisifikasika } \\
\text { n objek menurut } \\
\text { sifat-sifat tertentu } \\
\text { (4) }\end{array}$ & 2,1 & 2,94 & 0,44 & Sedang & 2,14 & 2,42 & 0,15 & Rendah \\
\hline $\begin{array}{l}\text { Mengaplikasikan } \\
\text { konsep atau } \\
\text { algoritma pada } \\
\text { pemecahan masalah } \\
\text { (4) }\end{array}$ & 1,7 & 2,62 & 0,40 & Sedang & 1,8 & 2,5 & 0,32 & Sedang \\
\hline Jumlah & 6,4 & 8,62 & & & 6,06 & 7,56 & \multirow{2}{*}{\multicolumn{2}{|c|}{ Rendah }} \\
\hline $\begin{array}{l}N \text {-gain Total } \\
\text { Seluruh Indikator }\end{array}$ & \multicolumn{2}{|c|}{0,39} & \multicolumn{2}{|c|}{ Sedang } & \multicolumn{2}{|c|}{0,25} & & \\
\hline
\end{tabular}

Berdasarkan hasil perhitungan normalitas data $N$-gain diketahui bahwa nilai $x^{2}{ }_{\text {hitung }}$ pada kelas eksperimen lebih kecil $x^{2}$ tabel yaitu 3,302 $\leq 7,815$, demikian pula untuk $x^{2}$ hitung pada kelas kontrol juga lebih kecil dari $x_{\text {tabel }}^{2}$ yaitu $-47,455 \leq 7,815$, untuk kelas eksperimen maupun kelas kontrol Ho diterima Ha ditolak. Hal ini dapat disimpulkan bahwa data $N$-gain pada kelas eksperimen dan kelas kontrol adalah berdistribusi normal.

Selanjutnya hasil perhitungan homogenitas $\mathrm{N}$-gain dengan mengunakan uji homogenitas variansi diperoleh $f_{\text {hitung }}=1,95$ dan $f_{\text {tabel }}=2,12$, sehingga $f_{\text {hitung }} \leq f_{\text {tabel }}$. Dengan demikian dapat disimpulkan bahwa nilai $\mathrm{N}$-gain dari kedua varians dari kelompok eksperimen dan kelompok kontrol adalah homogen. Sedangkan hasil perhitungan uji hipotesis dengan uji-t dua sampel diperoleh nilai $t_{\text {hitung }}$ lebih besar dari $t_{\text {tabel }}(2,919>2,064)$ yang menurut kriteria berarti Ho ditolak dan Ha diterima. Hal ini berarti terdapat perbedaan peningkatan kemampuan pemahaman konsep matematis siswa antara kelas eksperimen dan kelas kontrol pada materi logaritma kelas X MA Yasti Singkawang.

Hasil penelitian ini seiring dengan penelitian yang dilakukan Atiqah (2014) menyatakan bahwa kemampuan pemahaman konsep matematis siswa yang mendapat perlakuan lebih baik daripada pembelajaran konvensional. Sehingga dapat disimpulkan bahwa model Reciprocal Teaching efektif terhadap kemampuan pemahaman konsep matematis siswa.

\section{Aktivitas Belajar Siswa}

Data aktivitas siswa adalah data yang diperoleh dari hasil lembar pengamatan siswa selama mengikuti pembelajaran dengan menggunakan model pembelajaran Reciprocal Teaching. Dari hasil pengamatan dapat dinyatakan bahwa aktivitas belajar siswa aktif. Hal ini dapat dilihat dari lembar pengamatan aktivitas siswa yang diamati mulai dari proses pembelajaran sampai akhir pembelajaran. Selama proses pembelajaran berlangsung, secara keseluruhan siswa aktif mengikuti setiap aspek-aspek aktivitas yang diamati. Adapun cuplikan hasil pengamatan aktivitas belajar siswa akan disajikan pada Tabel 3.

Berdasarkan Tabel 3 dapat dilihat persentase rata-rata aktivitas pada pertemuan pertama dan pertemuan kedua pada kategori pengamatan Writing Activities dengan tiga aktivitas yang diamati yaitu siswa menulis hasil presentasi kelompok lain, membuat catatan dari materi logaritma, dan menyelesaikan LKS yang diberikan terdapat persentase sebesar $67,11 \%$ pada kriteria baik untuk 
pertemuan pertama. Kemudian pada pertemuan kedua aktivitas siswa mengalami peningkatan persentase yaitu sebesar $77,78 \%$ dalam kriteria sangat baik.

Tabel 3. Persentase Hasil Pengamatan Aktivitas Siswa

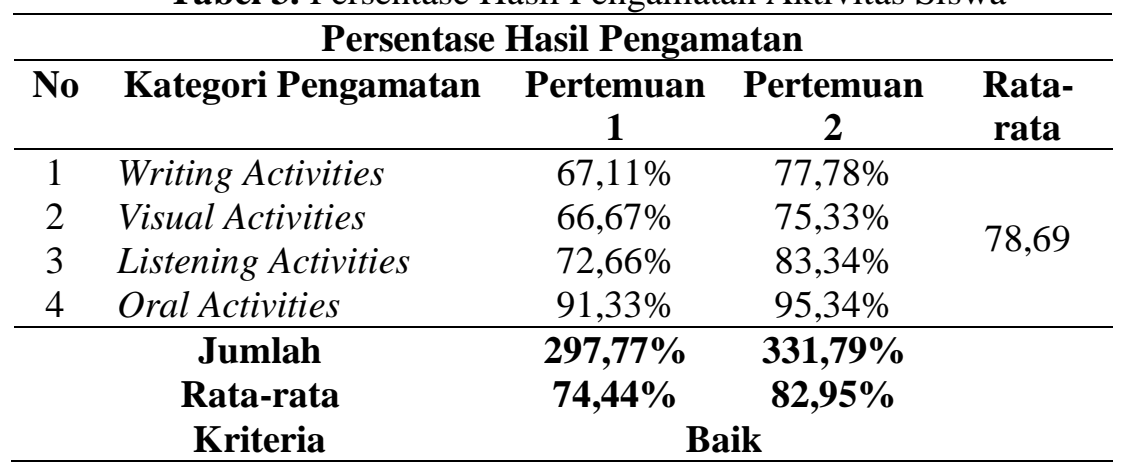

Pada kategori pengamatan Visual Activities dengan dua aktivitas yang diamati yaitu memperhatikan guru saat memberikan informasi dan memperhatikan kelompok lain menjelaskan hasil diskusi terdapat persentase sebesar 66,67\% dalam kriteria baik. Kemudian pada pertemuan kedua aktivitas siswa mengalami peningkatan dengan persentase sebesar $75,33 \%$ pada kriteria sangat baik. Pada kategori pengamatan Listening Activities dengan dua aktivitas yang diamati yaitu mendengarkan kelompok lain presentasi dan menyimak presentasi kelompok lain terdapat persentase sebesar 72,66\% dalam kriteria baik. Kemudian pada pertemuan kedua aktivitas siswa mengalami peningkatan dengan persentase $83,34 \%$ pada kriteria sangat baik. Pada kategori pengamatan Oral Activities dengan dua aktivitas yang diamati yaitu siswa bertanya jika belum dimengerti dan menjawab pertanyaan teman jika mengetahui jawabannya terdapat persentase sebesar $91,33 \%$ pada kriteria sangat baik. Kemudian pada pertemuan kedua aktivitas siswa mengalami peningkatan dengan persentase sebesar $95,34 \%$ pada kategori sangat baik.

Dari data persentase aktivitas siswa diperoleh rata-rata dari empat kategori pengamatan, dua kali pertemuan dan tiga orang pengamat yaitu $78,69 \%$. Hal ini menunjukkan bahwa aktivitas selama pembelajaran berlangsung berada pada kategori sangat baik. Dengan demikian dapat disimpulkan bahwa aktivitas siswa tergolong aktif pada pembelajaran materi logaritma dengan menggunakan model pembelajaran Reciprocal Teaching.

Hasil penelitian ini seiring dengan penelitian yang dilakukan oleh Sardiyanti (2013) dari hasil kesimpulan penelitiannya menyatakan bahwa model pembelajaran Reciprocal Teaching dapat meningkatkan aktivitas belajar siswa. Hal ini dapat dilihat dalam pelaksanaan siklus I dan II. Pada siklus I persentase rata-rata indikator keaktifan siswa 60,40\% yang kemudian meningkat pada siklus II menjadi $76,83 \%$ dan aktivitas siswa berada pada kriteria sangat baik.

\section{Kemandirian Belajar Siswa}

Angket diberikan kepada siswa dengan tujuan untuk mengetahui kemandirian belajar siswa dengan model pembelajaran Reciprocal Teaching. Untuk mengetahui hasil angket kemandirian digunakan rumus rata-rata seluruh angket dengan memilih kategori selalu (SL), sering (SR), kadang-kadang $(\mathrm{KD})$, pernah $(\mathrm{P})$, tidak pernah (TP). Model pembelajaran dikatakan positif apabila kriteria kemandirian belajar siswa berada pada kategori baik dan sangat baik. Adapun hasil angket kemandirian siswa dapat dilihat pada Tabel 4.

Berdasarkan Tabel 4 angket kemandirian siswa dapat diketahui bahwa pada indikator percaya diri terdapat dua pernyataan yaitu dengan model Reciprocal Teaching saya yakin bahwa setiap tugas yang saya kerjakan adalah benar dan saya percaya pada kemampuan saya sendiri bahwa saya akan berhasil dalam belajar memiliki nilai rata-rata 82,4 dengan kriteria sangat baik. Pada indikator bertanggung jawab terdapat dua pernyataan yaitu setiap ada pekerjaan rumah (PR) atau tugas dari bapak/ibu guru 
langsung saya kerjakan pada hari itu juga dan saya mengumpulkan pekerjaan rumah (PR) atau tugas yang diberikan bapak/ibu guru tepat waktu memiliki nilai rata-rata 80 dengan kategori baik.

Tabel 4. Hasil Angket Kemandirian Belajar Siswa

\begin{tabular}{|c|c|c|c|c|c|c|c|c|c|c|}
\hline \multirow{2}{*}{$\begin{array}{l}\mathbf{N} \\
\mathbf{0}\end{array}$} & \multirow{2}{*}{ Indikator } & \multirow{2}{*}{$\begin{array}{c}\text { No } \\
\text { Pernyataan }\end{array}$} & \multicolumn{5}{|c|}{ Pilihan jawaban } & \multirow{2}{*}{ Jumlah } & \multirow{2}{*}{$\begin{array}{l}\text { Rata- } \\
\text { rata }\end{array}$} & \multirow{2}{*}{ Kategor } \\
\hline & & & SL & SR & KD & $\mathbf{P}$ & TP & & & \\
\hline \multirow[b]{2}{*}{1} & & 5 & 9 & 10 & 6 & 0 & 0 & \multirow{2}{*}{206} & \multirow{2}{*}{82,4} & \multirow{2}{*}{$\begin{array}{c}\text { Sangat } \\
\text { baik }\end{array}$} \\
\hline & Percaya Dirı & 10 & 9 & 10 & 6 & 0 & 0 & & & \\
\hline \multirow{2}{*}{2} & Rertanorung Jawah & 3 & 8 & 10 & 7 & 0 & 0 & \multirow{2}{*}{200} & \multirow{2}{*}{80} & \multirow{2}{*}{ Baik } \\
\hline & Bertanggung Jawab & 4 & 7 & 10 & 8 & 0 & 0 & & & \\
\hline \multirow{2}{*}{3} & Inisiatif Belaiar & 2 & 10 & 9 & 6 & 0 & 0 & \multirow{2}{*}{201} & \multirow{2}{*}{80,4} & \multirow{2}{*}{ Baik } \\
\hline & inisiatit Beiajar & 7 & 6 & 10 & 9 & 0 & 0 & & & \\
\hline \multirow{2}{*}{4} & Disinlin & 1 & 6 & 10 & 9 & 0 & 0 & \multirow{2}{*}{200} & \multirow{2}{*}{80} & \multirow{2}{*}{ Baik } \\
\hline & & 9 & 11 & 6 & 8 & 0 & 0 & & & \\
\hline \multirow{3}{*}{5} & Memandang & 6 & 9 & 2 & 13 & 0 & 0 & \multirow[b]{2}{*}{195} & \multirow[b]{2}{*}{78} & \multirow[b]{2}{*}{ Baik } \\
\hline & $\begin{array}{l}\text { Kesulitan Sebagai } \\
\text { Tantangan }\end{array}$ & 8 & 9 & 10 & 6 & 0 & 0 & & & \\
\hline & Jumlah & & 84 & 87 & 78 & $\mathbf{0}$ & $\mathbf{0}$ & 1002 & 80,16 & Baik \\
\hline
\end{tabular}

Pada indikator inisiatif belajar terdapat dua pernyataan yaitu jika ada kesulitan dalam belajar menggunakan model Reciprocal Teaching saya biasanya mampu mengatasi masalah sendiri dan apabila ada soal-soal atau tugas yang sulit, saya berusaha untuk memecahkan sendiri tanpa meminta bantuan orang lain memiliki nilai rata-rata 80,4 dengan kategori baik. Pada indikator disiplin terdapat dua pernyataan yaitu sebelum belajar model Reciprocal Teaching saya menyiapkan buku-buku, alat tulis menulis, atau peralatan belajar lain yang saya perlukan dan saya belajar secara teratur tidak hanya akan ulangan saja memiliki nilai rata-rata 80 dengan kategori baik.

Pada indikator memandang kesulitan sebagai tantangan terdapat dua pernyataan yaitu dengan model Reciprocal Teaching jika ada materi pelajaran belum saya pahami saya berusaha mencari buku-buku perpustakaan untuk membantu memahami dan apabila ada soal-soal yang salah yang belum bisa saya jawab, saya berusaha untuk membetulkannya memiliki nilai rata-rata 78 dengan kategori baik. Dalam penelitian ini kemandirian belajar siswa dengan lima indikator memiliki nilai rata-rata sebesar 80,16 dengan kategori baik. Maka dapat disimpulkan bahwa kemandirian siswa positif terhadap model pembelajaran Reciprocal Teaching dalam meningkatkan kemampuan pemahaman konsep matematis siswa.

Hasil penelitian ini seiring dengan penelitian yang dilakukan oleh Rohkhana (2013) yang menyatakan bahwa model pembelajaran Reciprocal Teaching dapat meningkatkan kemandirian belajar siswa. Hal ini dapat dilihat dari hasil penelitian yang dilakukan sebanyak tiga putaran. Pada putaran I kemandirian siswa sebesar 36,76\%, putaran II kemandirian siswa sebesar 60,94\%, dan putaran III kemandirian siswa sebesar $83,83 \%$.

\section{KESIMPULAN}

Berdasarkan analisis data hasil penelitian yang dilakukan dan pembahasan secara umum dapat disimpulkan bahwa model pembelajaran Reciprocal Teaching efektif untuk meningkatkan kemampuan pemahaman konsep matematis siswa pada materi logaritma di kelas X MA Yasti Singkawang. Hal ini karena memenuhi keempat kriteria efektivitas yaitu (1) ketuntasan siswa mencapai KKM pada kelas eksperimen dengan menggunakan model Reciprocal Teaching di kelas X MA Yasti Singkawang, (2) terdapat perbedaaan peningkatan kemampuan pemahaman konsep matematis siswa setelah diberikan model pembelajaran Reciprocal Teaching pada materi logaritma di kelas X MA Yasti Singkawang, (3) aktivitas belajar siswa dinyatakan aktif selama kegiatan pembelajaran model Reciprocal Teaching pada materi logaritma di kelas X MA Yasti Singkawang, (4) 
kemandirian belajar siswa kelas eksperimen dinyatakan positif terhadap pembelajaran menggunakan model pembelajaran Reciprocal Teaching pada materi logaritma kelas X di MA Yasti Singkawang.

\section{DAFTAR PUSTAKA}

Atiqah, Nurul. (2014). Penerapan Model Reciprocal Teaching pada Pembelajaran MAtematika Siswa Kelas VIII SMPN 26 Padang. Jurnal Pendidikan Matematika FMIPA UNP, 2(2), 85-93.

Buyung., Nirawati, R., \& Kusumawati, I. (2016). Pengaruh Strategi Pembelajaran Inkuiri (SPI) Terhadap Kemampuan Pemahaman Konsep Siswa Kelas VIII SMP Negeri 18 Singkawang. Jurnal Pendidikan Matematika Indonesia, 1(2), 87-90.

Danianti. (2013). Pengaruh Intelegensi dan Kemandirian Belajar terhadap Hasil Belajar Matematika Siswa Kelas VIII SMP N 7 Kota Jambi. Jurnal Pendidikan Matematika, 1(2), 22-32.

Darmadi, Hamid. (2014). Metode Penelitian Pendidikan dan Sosial. Bandung: Alfabeta.

Elcho, Muhammad. (2014). Efektivitas Penerapan Reciprocal Teaching Ditinjau Dari Pemahaman Konsep Matematis Siswa. Jurnal Pendidikan Matematika, 3(1), 105-113.

Huda, Miftahul. (2014). Model-Model Pengajaran Dan Pembelajaran. Yogyakarta: Pustaka Pelajar.

Jihad dan Haris. (2012). Evaluasi Pembelajaran. Yogyakarta: Multi Presindo.

Juliyanti., Rosmaiyadi., \& Mariyam. (2018). Pemahaman Konep Matematis Siswa Dengan Strategi Pembelajaran Group To Group Exchange Berpendekatan Kontekstual. Jurnal Penelitian dan Pembelajaran Matematika, 11(1), 149-159.

NCTM (National Council of Teacher of Mathematics). (2000). Principles and Standars for School Mathematics.Virginia: Reston.

Rohkhana, Siti. (2013). Efektivitas Pembelajaran Reciprocal Teaching Sebagai Upaya Meningkatkan Kemandirian dan Hasil Belajar Matematika. Jurnal Pendidikan Matematika, 3(2), 25-34.

Ruseffendi. (2006). Pengantar Kepada Membantu Guru mengembankan Kompetensinya dalam Pengajaran Matematika Untuk Meningkatkan CBSA. Bandung: Tarsito.

Sardiman. (2014). Interaksi Motivasi Belajar Mengajar. Jakarta: PT Rajagrafindo.

Sardiyanti. (2013). Penerapan Model Pembelajaran Terbalik (Reciprocal Teaching) untuk Meningkatkan Aktivitas Belajar Matematika Siswa. Jurnal Pendidikan Matematika, 4(2), 8999.

Vahlia, Ira. (2015). Penerapan Model Pembelajaran Berbalik (Reciprocal Teaching) Ditinjau dari Aktivitas dan Hasil Belajar Siswa. Jurnal Pendidikan Matematika, 4(2), 60-69. 